\title{
H2AX Gene
}

National Cancer Institute

\section{Source}

National Cancer Institute. H2AX Gene. NCI Thesaurus. Code C28582.

This gene is involved in histone and nucleosome org anization and chromatin compaction regulation. 